\title{
HUBUNGAN TINGKAT PENGETAHUAN TENTANG KEPUTIHAN DENGAN PERILAKU PENCEGAHAN KEPUTIHAN PADA REMAJA PUTRI DI SMA DHARMA PRAJA DENPASAR
}

\author{
THE CORRELATION BETWEEN LEVEL OF \\ KNOWLEDGE ABOUT LEUCORRHOEA AND \\ PREVENTION OF LEUCORRHOEA BEHAVIOR ON \\ TEENAGE GIRLS AT SMA DHARMA PRAJA \\ DENPASAR
}

\author{
Ni Ketut Citrawati' ${ }^{1,}$ Herminia Carolina $\mathrm{Nay}^{2}$, R. Tri Rahyuning Lestari ${ }^{3}$. \\ STIKes Wira Medika Bali ${ }^{123}$
}

\begin{abstract}
ABSTRAK
Keputihan atau Fluor albus adalah suatu gejala berupa cairan yang tidak berupa darah yang keluar dari organ genetalia. Di Indonesia sekitar $90 \%$ wanita berpotensi mengalami keputihan karena negara Indonesia adalah daerah yang beriklim tropis, sehingga jamur muda berkembang yang mengakibatkan banyaknya kasus keputihan. Keputihan pada remaja dapat disebabkan karena perilaku pencegahan keputihan yang kurang baik. Pengetahuan adalah salah satu faktor terbentuknya perilaku pada remaja. Penelitian ini bertujuan untuk menganalisa hubungan tingkat pengetahuan tentang keputihan dengan perilaku pencegahan keputihan pada remaja putri di SMA Dharma Praja Denpasar. Jenis penelitian yaitu kuantitatif dengan menggunakan metode desain korelasi deskriptif dengan pendekatan cross sectional. Populasi dalam penelitian ini adalah pelajar yang berjenis kelamin perempuan kelas X di SMA Dharma Praja sebanyak 124 orang. Teknik pengambilan sampel yaitu menggunakan teknik simple random sampling dengan jumlah sampel sebanyak 95 responden. Uji statistik menggunakan uji korelasi Spearman Rank. Hasil penelitian menunjukkan remaja dengan pengetahuan yang baik tentang keputihan lebih banyak memiliki perilaku yang baik dalam pencegahan keputihan $(82,3 \%)$. Hasil uji statistik menunjukkan ada hubungan yang signifikan dengan kekuatan kuat antara tingkat pengetahuan tentang keputihan dengan perilaku pencegahan keputihan pada remaja putri di SMA Dharma Praja Denpasar, dengan nilai signifikansi yaitu sebesar 0,000 dengan nilai koefisien korelasi yaitu 0,722 . Semakin tinggi pengetahuan remaja maka akan semakin baik perilaku remaja terhadap pencegahan keputihan. Berdasarkan penelitian ini, disarankan bagi tenaga kesehatan diharapkan dapat bekerjasama dengan sekolah dalam memberikan informasi kepada siswi tentang kesehatan reproduksi khususnya keputihan.
\end{abstract}

Kata Kunci : Keputihan, Pengetahuan, Perilaku

\section{ABSTRACT}

Leucorrhoea is a symptom in the form of a liquid that is not in the form of blood coming out of genetal organs. In Indonesia, about $90 \%$ of women have the potential to 
experience leucorrhoea because the country of Indonesia is a tropical climate, so young fungi develop which result in many cases of leucorrhoea. Leucorrhoea in teenagers can be caused by bad behavior of leucorrhoea precaution. Knowledge is a factor to build behavior in teenager. This study aims to analyze the correlation between level knowledge about leucorrhoea with prevention behavior leucorrhoea for teenage girls at SMA Dharma Praja Denpasar. The type of research is quantitative by using descriptive correlation design method with cross sectional approach. The population in this study were female students of class X at SMA Dharma Praja Denpasar as many 124 people. The technique sampling is using simple random sampling with total sample of 95 respondents. Statistical tests using the Spearman Rank correlation test. The results showed that more teenager with good knowledge of leucorrhoea have good behavior in leucorrhoea precaution (82.3\%). The results of the statistical tests show that there is a significant correlation with the strong strength between knowledge about Leucorrhoea with prevention behavior leucorrhoea for teenage girls at Sma Dharma Praja Denpasar, with a significance value of 0,000 with a correlation coefficient of 0.722. The higher adolescent's knowledge, it will better for behavior of adolescents towards prevention of leucorrhoea. Based on this study, it is recommended that health workers be expected to work together with schools in providing information to students about reproductive health, especially leucorrhoea.

Keywords: Leucorrhoea, Knowledge, Behavior

\begin{tabular}{ll}
\hline Alamat Korespondensi & : Jalan Kecak No. 9A Gatot Subroto Timur Denpasar \\
Email & : herlinanay@gmail.com
\end{tabular}

\section{PENDAHULUAN}

Keputihan bukan merupakan golongan penyakit tersendiri, tetapi merupakan salah satu tanda dan gejala dari suatu penyakit organ reproduksi wanita yang harus diobati (Manuaba, 2009). Keputihan diklasifikasikan menjadi 2 yaitu keputihan normal dan abnormal. Keputihan normal adalah cairan yang keluar dari vagina yang berwarna putih yang biasanya keluar menjelang haid, sedangkan keputihan yang abnormal adalah cairan kental berwarna putih susu/hijau, berbau, dan terasa gatal. Keputihan abnormal dapat menyebabkan infeksi atau peradangan, ini terjadi karena perilaku yang tidak benar dalam menjaga dan merawat kebersihan pada alat genetalia (Kusmiran, 2011).

Data penelitian yang diperoleh dari World Hellt Organization (WHO, 2010) masalah kesehatan reproduksi perempuan yang buruk telah mencapai $33 \%$ dari jumlah total beban penyakit yang di derita pada perempuan didunia salah satunya keputihan. Sekitar 75\% wanita dunia pasti mengalami keputihan paling tidak sekali dalam seumur hidup dan 45\% diantaranya dapat mengalami keputihan sebanyak 2 kali atau lebih. Di Indonesia sekitar 90\% wanita berpotensi mengalami keputihan karena negara Indonesia adalah daerah yang beriklim tropis, sehingga jamur muda berkembang yang mengakibatkan banyaknya kasus keputihan (Azizah \& Widiawati, 2015). Berdasarkan data dari Dinas Kesehatan Provinsi Bali menunjukkan, bahwa total kasus IMS disertai gejala keputihan pada tahun 2015 sebanyak 5.698 orang (Sulasmini, 2016). Menurut data dari Dinas Kesehatan Kota Denpasar data kasus IMS dengan disertai gejala keputihan tertinggi yaitu wilayah Denpasar Utara 1.542 kasus.

Dampak keputihan abnormal yaitu infeksi oleh kuman atau bakteri yang masuk ke vagina sehingga terjadi keputihan yang berlanjut ke tahap lebih parah dan 
berisiko untuk terjadi kasus Infeksi Menular Seksual (IMS), hal ini begitu buruk bagi remaja putri yang kelak akan menikah dan sebagai penular kepada suaminya sebagai pasangan seksual (BKKBN, 2012).

\section{Cara Mengatasi Keputihan Secara Alami Dari Tumbuhan (Herbal)}

1. Daun Sirih

Nama ilmiah daun sirih adalah Piper betle L. daun sirih mengandung minyak asiri yang terdiri dari berbagai senyawa seperti: kavikol, karvakol, sineol, metal kavikol, eugenol, eugenol metal eter dan kavibetol. Selain itu juga daun sirih mengandung tannin, gula dan amilun. Daun sirih mempunyai efek farmakologi seperti meredakan batuk, anti radang, merangsang saraf pusat, meredakan sifat mendengkur, mencegah ejakulasi premature, keputihan, menghentikan perdarahan dan menguatkan gigi. Adapun cara yang bisa di lakukan dengan membuat ramuan untuk keputihan yaitu siapkan daun sirih segar 10 lembar kemudian daun sirih di rebus 2,5 liter air. Dalam kondisi hangat air rebusan daun sirih di pakai untuk memcuci liang kemaluan.

2. Kunyit

Kunyit adalah salah satu obat alami keputihan yang termasuk dalam jenis umbi-umbian. Kunyit terdiri dari dua jenis yaitu kunyit putih dan kuning, tetapi yang paling sering digunakan adalah kunyit kuning. Kunyit mengandung senyawa yang berkhasiat obat, yang di sebut kurkuminoid yang terdiri dari kurkumin, desmetoksikumin dan bisdesmetoksikurkumin dan zat-zat manfaat lainnya. Adapun cara yang digunakan untuk membuat ramuan untuk keputihan yaitu ambil 2 rimpang kunyit, satu genggam daun beluntas, satu genggam buah asam dan satu potong gula aren. Selanjutnya semua bahan di rebus secara bersamaan dengan 1liter air sampai mendidih kemudian di saring. Air rebusan ini dapat dikonsumsi 1 gelas per hari.

Remaja merupakan masa transisi dari masa kanak-kanak menuju dewasa, dimana terjadi pacu tumbuh seperti timbul ciri-ciri seksual sekunder contohnya, tercapainya fertilitas dan terjadi perubahan psikologi dan kognitif (Mareta, 2012). Menurut Sarwono (2011), klasifikasi pada remaja dibagi menjadi sebagai berikut: Remaja awal (early adolescence), dengan rentang usia 11-13 tahun, Remaja pertengahan (middle adolescence), dengan rentang usia 14-16 tahun dan Remaja akhir (late adolescence), dengan rentang usia 17-20 tahun.

Pada remaja, penyebab keputihan adalah perilaku pencegahan keputihan yang kurang baik, yaitu hygiene yang buruk setelah buang air kecil dan buang air besar, menyebabkan patogen mengkontaminasi vulva. Cuci tangan yang tidak adekuat dapat mengiritasi atau kontaminasi bakteri pada vulva. Pakaian ketat, celana dalam yang tidak menyerap juga dapat menyebabkan iritasi. Memakai celana dalam yang terbuat dari katun. Kain katun menyerap lembab dan memberikan sirkulasi udara yang bebas ke area genitalia. Lembab dapat meningkatkan infeksi vagina tertentu. Tidak memakai pakaian yang ketat untuk memberikan sirkulasi udara yang lebih baik. Celana atau jeans yang ketat dapat menyebabkan lembab terperangkap dan menyebabkan iritasi. Hindari penggunaan pengharum atau sabun deodorant, mandi busa dan tisu berwarna. Mereka mengandung bahan kimia yang dapat mengiritasi vagina dan genitalia eksterna. Hindari bilas vagina, karena akan menghilangkan flora normal dri vagina dan jika ada infeksi akan menyebabkan berpindahnya patogen ke alat genitalia yang lebih tinggi. Mengganti pembalut paling sedikit tiga 
kali sehari. Jika pembalut terlalu banyak menyerap lembab, akan menyebabkan iritasi. Bersihkan genitalia dari depan ke belakang. Bakteri dari daerah rektal dapat menyebabkan infeksi vagina. Hindari penggunaan pakaian maupun handuk orang lain. Remaja yang memiliki pengetahuan yang baik tentang keputihan cenderung memiliki perilaku yang baik tentang pencegahan keputihan.

Pengetahuan adalah sesuatu yang ada dikepala yang kita peroleh dari hasil penginderaan sehingga semakin banyak yang diperoleh dapat mempengaruhi atau menambah pengetahuan. Pemahaman remaja akan kesehatan reproduksi menjadi bekal remaja dalam berperilaku sehat dan bertanggung jawab, namun tidak semua remaja memperoleh informasi yang cukup dan benar tentang kesehatan reproduksi. Keterbatasan pengetahuan dan pemahaman ini dapat membawa remaja ke arah perilaku beresiko (Kumalasari dan Andhyantoro, 2012). Budiman dan Riyanto (2013) menjelaskan faktor-faktor yang mempengaruhi pengetahuan adalah sebagai berikut : Pendidikan, Media masa/informasi, Sosial budaya dan Usia.

Masalah keputihan adalah masalah yang sejak lama menjadi persoalan bagi kaum wanita. Tidak banyak wanita yang tahu apa itu keputihan dan terkadang menganggap enteng persoalan tentang keputihan pada wanita. Akibat dari keputihan ini bisa sangat fatal bila lambat ditangani. Dampak yang ditimbulkan bila terjadi keputihan yaitu tidak hanya bisa mengakibatkan kemandulan dan hamil diluar kandungan, keputihan juga bisa merupakan gejala awal dari kanker leher rahim yang bisa berujung pada kematian.

SMA Dharma Praja Denpasar merupakan sekolah swasta Akreditasi A yang berada pada naungan Kementerian Pendidikan dan Kebudayaan yang terletak di Jalan Jend. Gatot Subroto Denpasar No. 376, RT/RW 0/0, Dusun. Dauh Puri Kaja, Kecamatan Denpasar Utara, Kota Denapsar, Provinsi Bali. Berdasarkan hasil studi pendahuluan pada bulan Agustus 2018 di SMA Dharma Praja, di peroleh data jumlah remaja putri kelas X sebanyak 124 orang yang terdiri dari 7 kelas. Saat melakukan wawancara, siswi mengatakan bahwa belum pernah mendapatkan penyuluhan tentang Keputihan di sekolah. Berdasarkan hasil wawancara dari 10 orang siswi didapatkan hasil yaitu terdapat enam diantaranya pernah mengalami keputihan dan tidak mengetahui apa penyebabnya, enam orang siswi mengaku keputihan yang dialaminya kadang berwarna putih dan sampai kekuningan, berbau, dapat keluar kapan saja dan terasa gatal, sedangkan empat orang siswi mengalami keputihan berwarna bening dan mengalaminya saat sebelum menstruasi. Tiga dari enam siswi yang mengalami keputihan tersebut mengaku sering menggunakan antiseptik sebagai pembersih daerah vagina dan tiga diantaranya sering menggunakan panty liner dan menggunakan celana dari bahan yang tidak mudah menyerap keringat dan ketat.

Berdasarkan urain di atas, perlu diketahui mengenai tingkat pengetahuan dan perilaku pencegahan keputihan pada remaja putri. Untuk itu perlu dilakukan penelitian tentang hubungan tingkat pengetahuan tentang keputihan dengan perilaku pencegahan keputihan pada remaja putri di SMA Dharma Praja Denpasar.

\section{METODE PENELITIAN}

Penelitian ini menggunakan desain korelasi deskriptif, yaitu bertujuan untuk mengetahui hubungan yang terjadi pada sebuah fenomena (Putra, 2012). Pendekatan yang digunakan adalah cross sectional, yaitu peneliti hanya melakukan 
observasi dan pengukuran variabel pada satu saat tertentu saja. Pengukuran variabel tidak terbatas harus tepat pada satu waktu bersamaan, namun mempunyai makna bahwa setiap subyek hanya dikenai satu kali pengukuran, tanpa dilakukan tindak lanjut, atau pengulangan pengukuran, yang bertujuan untuk mengetahui gambaran sejauh mana hubungan antara variabel tingkat pengetahuan tentang keputihan dengan perilaku pencegahan keputihan pada remaja putri (Saryono dan Anggraeni, 2013). Penelitian ini dilaksanakan di SMA Dharma Praja, Kecamatan Denpasar Utara, Kota Denpasar, Provinsi Bali pada tanggal 3 November 2018. Populasi pada penelitian ini adalah pelajar yang berjenis kelamin perempuan kelas X di SMA Dharma Praja sebanyak 124 orang. Besar sampel dalam penelitian ini berjumlah 95 siswi. Sampel dalam penelitian diambil menggunakan teknik Probability Sampling, yaitu teknik pengambilan sampel dengan memberikan peluang yang sama bagi setiap unsur (anggota) populasi untuk dipilih menjadi anggota sampel (Sugiyono, 2011). Teknik probability sampling yang digunakan dalam penelitian ini adalah dengan simple random sampling yaitu pengambilan sampel berdasarkan atas teknik undian. Caranya adalah peneliti menuliskan nomor absen dari seluruh populasi tiap kelas siswi kelas X SMA Dharma Praja Denpasar pada guntingan kertas kecil, satu kertas untuk satu nomor absen, kemudian peneliti menggulung kertas tersebut dan mengambil gulungan kertas tersebut sebanyak jumlah sampel tiap kelas yang telah ditentukan untuk dijadikan sampel penelitian. Variabel bebas dalam penelitian ini adalah pengetahuan tentang keputihan dan Varibel terikat dalam penelitian ini adalah perilaku pencegahan keputihan pada remaja putri. Penelitian ini menggunakan kuesioner pengetahuan tentang keputihan di peroleh dari Novi (2017) dan kuesioner Perilaku pencegahan keputihan di peroleh dari Ni Kadek Dian Lestari (2017). Analisa univariat dalam penelitian ini dilakukan terhadap setiap variabel yaitu tingkat pengetahuan tentang keputihan, perilaku pencegahan keputihan disajikan dalam bentuk tabel distribusi frekuensi dan Analisis bivariat yang dilakukan pada penelitian ini yaitu untuk mengetahui hubungan variabel bebas (independent) yaitu Tingkat Pengetahuan Tentang Keputihan dan variabel terikat (dependent) yaitu Perilaku pencegahan keputihan. Untuk mengetahui hal tersebut, variabel-variabel tersebut harus diuji dengan menggunakan Uji korelasi Spearman Rank dengan menggunakan program komputer SPSS. Korelasi Spearman Rank adalah uji statistik yang ditujukan untuk mengetahui hubungan antara dua atau lebih variabel berskala ordinal (Sugiyono, 2011). Dengan ketentuan jika nilai sig. $<0.05$ maka dapat disimpulkan bahwa terdapat korelasi yang signifikan antara variabel yang dihubungkan. Jika nilai sig. $>0,05$ maka dapat disimpulkan bahwa tidak terdapat korelasi yang signifikan antara variabel yang dihubungkan.

\section{HASIL DAN PEMBAHASAN}

\section{HASIL}

\section{Hasil Pengamatan Terhadap Obyek Penelitian Berdasarkan Variabel Penelitian}

\section{Tingkat pengetahuan tentang keputihan}

Hasil pengamatan terhadap tingkat pengetahuan tentang keputihan dijelaskan pada tabel 1 sebagai berikut. 
Tabel 1. Tingkat pengetahuan tentang keputihan

\begin{tabular}{clcc}
\hline No & Kategori & Frekuensi (f) & $\begin{array}{c}\text { Presentase } \\
(\mathbf{\%})\end{array}$ \\
\hline 1 & Kurang & 9 & 9,5 \\
2 & Cukup & 24 & 25,3 \\
3 & Baik & 62 & 65,3 \\
\hline \multirow{2}{*}{ Total } & $\mathbf{9 5}$ & $\mathbf{1 0 0}$ \\
\hline
\end{tabular}

\section{Perilaku pencegahan keputihan}

Hasil pengamatan terhadap Perilaku pencegahan keputihan dijelaskan pada tabel 2 sebagai berikut

Tabel 2. Perilaku pencegahan keputihan

\begin{tabular}{clcc}
\hline No & Kategori & Frekuensi (f) & Presentase (\%) \\
\hline 1 & Kurang & 10 & 10,5 \\
2 & Cukup & 31 & 32,6 \\
3 & Baik & 54 & 56,8 \\
\hline \multirow{4}{*}{ Total } & $\mathbf{9 5}$ & $\mathbf{1 0 0}$ \\
\hline
\end{tabular}

\section{Analisa Data}

Hasil analisa digunakan untuk menganalisa hubungan tingkat pengetahuam tentang keputihan dengan perilaku pencegahan keputihan pada remaja putri kelas X SMA Dharma Praja Denpasar menggunakan uji Lambda uji Spearman Rank. Berdasarkan hasil uji didapatkan nilai $\mathrm{p}=0,000(\mathrm{p}<0,05)$, hal ini menunjukkan ada hubungan bermakna antara hubungan tingkat pengetahuam tentang

Keputihan dengan perilaku pencegahan keputihan pada remaja putri kelas $\mathrm{X}$ SMA Dharma Praja Denpasar. Nilai koefisien korelasi (r) $=0,722$ menunjukkan ada hubungan korelasi kuat artinya semakin tinggi pengetahuan remaja maka akan semakin baik perilaku remaja terhadap pencegahan keputihan $(82,3 \%)$. (lihat tabel3.).

Tabel 3. Hasil analisis hubungan tingkat pengetahuam tentang keputihan dengan perilaku pencegahan keputihan pada remaja putri kelas X SMA Dharma Praja Denpasar

\begin{tabular}{|c|c|c|c|c|c|c|c|c|c|c|}
\hline \multirow{3}{*}{$\begin{array}{c}\text { Tingkat } \\
\text { Pengetahuan } \\
\text { Tentang Keputihan }\end{array}$} & \multicolumn{6}{|c|}{ Perilaku Pencegahan Keputihan } & \multicolumn{2}{|c|}{ Total } & \multirow{3}{*}{$\begin{array}{c}p \\
\text { value }\end{array}$} & \multirow{3}{*}{$\mathbf{r}$} \\
\hline & \multicolumn{2}{|c|}{ Kurang } & \multicolumn{2}{|c|}{ Cukup } & \multicolumn{2}{|c|}{ Baik } & & & & \\
\hline & $f$ & $\%$ & $f$ & $\%$ & $f$ & $\%$ & $f$ & $\%$ & & \\
\hline Kurang & 4 & 44,4 & 5 & 55,6 & 0 & 0 & 9 & 100 & & \\
\hline Cukup & 5 & 20,8 & 16 & 66,7 & 3 & 12,5 & 24 & 100 & & \\
\hline Baik & 1 & 1,6 & 10 & 16,1 & 51 & 82,3 & 62 & 100 & $n 000$ & 0702 \\
\hline Total & 10 & 10,5 & 31 & 32,6 & 54 & 56,8 & 95 & 100 &, 000 & $0, / 22$ \\
\hline
\end{tabular}




\section{PEMBAHASAN}

Hasil penelitian tingkat pengetahuan tentang keputihan dengan perilaku pencegahan keputihan pada remaja putri kelas X menunjukkan bahwa sebagian besar remaja putri kelas X SMA Dharma memiliki pengetahuan dan perilaku yang baik dalam pencegahan keputihan $(82,3 \%)$.

Hasil penelitian ini sejalan dengan penelitian yang dilakukan oleh Putri dan Warsiti (2013) menunjukkan pengetahuan dan perilaku pada remaja putri di SMA Negeri 2 Wonosari Gunung Kidul sebagian besar kategori baik. Dalam uraian tersebut, bahwa seseorang yang memiliki perilaku baik maka semakin kecil kemungkinan akan mengalami keputihan.

Hasil penelitian tentang pengetahuan tentang keputihan dalam kategori kurang sebanyak 9 orang dengan persentase $9,5 \%$, responden yang memiliki pengetahuan tentang keputihan dalam kategori cukup 24 orang dengan persentase $25,3 \%$, dan responden yang memiliki pengetahuan tentang keputihan dalam kategori baik yaitu sebanyak 62 orang dengan persentase $65,3 \%$.

Pengetahuan seseorang terhadap suatu objek mempunyai intensitas atau tingkat yang berbeda-beda. Sumber informasi, pendidikan, sosial budaya dan ekonomi, lingkungan, pengalaman dan usia dapat mempengaruhi pengetahuan seseorang. Pengetahuan adalah hasil dari tahu, dan hasil tersebut akan diperoleh setelah orang melakukan penginderaan terhadap suatu objek tertentu. Pengindraan terjadi melalui panca indera manusia, yakni indera penglihatan, pendegaran, penciuman,rasa, dan raba. Sebagaian besar pengetahuan manusia diperoleh dari mata dan telinga. Sebagian banyak informasi mempengaruhi atau menambah pengetahuan seseorang, dan dengan pengetahuan menimbulkan kesadaran yang akhirnya seseorang akan berperilaku sesuai dengan pengetahuan yang dimilikinya (Notoatmodjo, 2007).

Menurut Budiman dan Riyanto (2013) faktor yang mempengaruhi pengetahuan adalah Pendidikan. Pendidikan mempengaruhi proses belajar, semakin tinggi pendidikan seseoarang maka semakin mudah orang tersebut untuk menerima infomasi tentang keputihan.

Hasil penelitian tentang perilaku pencegahan keputihan dalam kategori kurang yaitu sebanyak 10 orang dengan persentase $10,5 \%$, responden yang memiliki perilaku pencegahan keputihan dalam kategori cukup sebanyak 31 orang dengan persentase $32,6 \%$ dan responden yang memiliki perilaku pencegahan keputihan dalam kategori baik sebanyak 54 orang dengan persentase 56,8\%.

Menurut Teori Model Keperawatan (2011) perilaku dipengaruhi oleh nilai harapan, dimana perilaku sehat adalah rasional dan ekonomis. Secara spesifik seseorang akan bertindak dan akan tetap mempertahankan hasil yang ingin dicapai melaui nilai yang baik dan untuk hasil yang baik, dengan demikian seseorang tersebut juga harus mempunyai informasi dan pengetahuan yang baik. Hal ini terlihat bahwa pengetahuan dan perilaku saling berhubungan pada individu untuk berpartisipasi dalam perilaku peningkatan kesehatan yaitu, perilaku untuk gaya hidup bersih sehingga kemungkinan kejadian keputihan sangat kecil.

Perilaku pencegahan keputihan adalah usaha untuk mempertahankan atau memperbaiki kesehatan dengan memelihara kebersihan organ reproduksi. Dalam kehidupan sehari-hari, kebersihan merupakan hal yang sangat penting dan harus diperhatikan karena kebersihan mempengaruhi kesehatan dan psikis seseorang. Salah satu faktor yang mempengaruhi perilaku yaitu faktor motivasi dimana 
motivasi merupakan dorongan dari dalam diri manusia untuk bertindak atau berperilaku. (Notoadmojo, 2012).

Berdasarkan hasil uji statistik korelasi Rank Spearman pada tingkat kemaknaan $\alpha=0,05$ diperoleh hasil $p=0,000(p<\alpha)$. Nilai koefisien korelasi sebesar 0,722 (interval koefisien sebesar 0,60-0,799) menunjukkan adanya hubungan yang kuat. Artinya semakin tinggi pengetahuan remaja maka akan semakin baik perilaku remaja terhadap pencegahan keputihan. Dapat disimpulkan bahwa ada hubungan yang signifikan dengan kekuatan kuat antara tingkat pengetahuan tentang keputihan dengan perilaku pencegahan keputihan pada remaja putri kelas X SMA Dharma Praja Denpasar.

Remaja yang memiliki pengetahuan tentang keputihan akan mempunyai pemahaman yang baik sehingga dapat mencegah keputihan, sebaliknya remaja yang memiliki pengetahuan yang kurang tentang keputihan akan mempunyai perilaku yang kurang baik juga dalam mencegah keputihan. Pengetahuan yang kurang dapat disebabkan karena remaja tidak memahami atau hanya menerima informasi yang tidak menyeluruh. Seharusnya, remaja mempunyai kesempatan untuk mendapatkan informasi mengenai kesehatan reproduksi baik dari tenaga kesehatan, guru maupun dari media-media yang ada. Kesempatan yang besar ini diharapkan dapat lebih meningkatkan pengetahuan tentang keputihan, sehingga remaja dapat melakukan perilaku pencegahan keputihan sehari-hari dengan baik dan benar. Remaja yang melakukan perilaku pencegahan keputihan dengan baik, diharapkan dapat meningkatkan derajat kesehatannya (Indriyani, 2012).

Berdasarkan hasil penelitian yang telah dilakukan, diperoleh sebagian besar responden memiliki pengetahuan dan perilaku yang baik. Peneliti berpendapat bahwa untuk mempertahankan pengetahuan dan perilaku remaja putri yang baik perlu dilakukan pembinaan melalui penyuluhan baik oleh petugas kesehatan maupun guru di sekolah dengan lebih menekankan pentingnya kesehatan reproduksi. Semakin baik pengetahuan remaja putri maka semakin baik pula perilaku remaja putri dalam mengatasi masalah kesehatan reproduksi khususnya keputihan.

\section{Simpulan}

\section{SIMPULAN DAN SARAN}

Berdasarkan analisa dan pembahasan tentang hubungan tingkat pengetahuan tentang keputihan dengan perilaku pencegahan keputihan pada remaja putri kelas $\mathrm{X}$ yang telah diuraikan sebelumnya, dapat ditarik kesimpulan Hasil pengukuran tingkat pengetahuan tentang keputihan didapatkan hasil sebagian besar responden memiliki pengetahuan baik yaitu sebanyak 62 orang $(65,3 \%)$. Hasil pengukuran perilaku pencegahan keputihan didapatkan hasil sebagian besar responden memiliki perilaku yang baik yaitu sebanyak 54 orang $(56,8 \%)$. Hasil analisa data dengan korelasi Rank Spearman didapatkan nilai $\mathrm{p}=0,000$ dengan koefisien korelasi bernilai positif yaitu sebesar 0,722 artinya ada hubungan yang signifikan antara tingkat pengetahuan tentang keputihan dan perilaku pencegahan keputihan pada remaja putri kelas X SMA Dharma Praja Denpasar menunjukkan korelasi memiliki keeratan yang kuat dengan kesimpulan semakin tinggi pengetahuan remaja maka akan semakin baik perilaku remaja terhadap pencegahan keputihan. 


\section{Saran}

Bagi tenanga kesehatan diharapkan dapat bekerjasama dengan sekolah dalam memberikan informasi kepada siswa tentang kesehatan reproduksi remaja. Sehingga siswa yang mengalami perubahan-perubahan pada organ reproduksinya khususnya pada siswi putri siap dalam menghadapi keputihan

\section{DAFTAR PUSTAKA}

Azizah dan Widiawati 2015. Karakteristik Remaja Putri dengan kejadian Keputihan Di SMK Muhammadiyah Kudus, V1, 57-58.

Badan Kependudukan dan Keluarga Berencana Nasional. 2012. Infeksi Menular Seksual dan HIV/AIDS. Jakarta: UNESCO.

Budiman, dan Riyanto. 2013. Kapita Selekta Kuesioner Pengetahuan Dan Sikap Dalam Penelitian Kesehatan. Jakarta : Salemba Medika pp 66-69.

Kumalasari dan Andyantoro. 2012. Kesehatan reproduksi untuk mahasiswa kebidanan dan keperawatan. Jakarta : Salemba Medika.

Kusmiran, 2011. Kesehatan Reproduksi Remaja dan Wanita. Jakarta: Salemba Medika.

, 2012. Kesehatan Reproduksi Remaja dan Wanita . Jakarta: Salemba Medika.

Manuaba. 2009a. Gadar Obstetri \& Ginekologi \& Obstetri Ginekologi Sosial Untuk Profesi Bidan, Jakarta: Salemba Medika. , 2009b. Memahami Kesehatan Reproduksi Wanita. Edisi 2. Jakarta: EGC. ,2009c. Memahami Kesehatan Reproduksi Perempuan. Jakarta: EGC.

Mareta. 2012. Hubungan Tingkat Pengetahuan Remaja Putri Tentang Personal Hygiene Dengan Tindaka Pencegahan Keputihan Di Sma Negeri 9 Semarang. Journal Internasional, 2.

Ni Kadek Dian Lestari. 2017. Hubungan Pengetahuan Tentang Perawatan Vulva Dengan Perilaku Pencegahan Keputihan Pada RemajA Putri Kelas X. Jurusan S1 Keperawatan. STIKes Wira Medika Bali.

Notoatmodjo. 2007. Promosi Kesehatan dan Ilmu Perilaku. Jakarta: Rineka Cipta. . 2010. Promosi Kesehatan Teori dan Aplikasi, Jakarta: Rineka Cipta. 2012. Promosi Kesehatan dan Perilaku Kesehatan. Jakarta: Rineka Cipta.

Novi Nur Anggarini. 2017. Gambaran Tingkat Pengetahuan Tentang Keputihan Pada Remaja Putri Kelas X Sma Negeri 1 Godean Kabupaten Sleman Yogyakarta. Jurnal Kebidanan.

Putra, S. R. 2012. Panduan Riset Keperawatan Dan Penulisan Ilmiah. Jogjakarta : D-Medika

Sarwono. 2011. Psikologi Remaja. Jakarta: PT Raja Grafindo Persada.

Sugiyono. 2010. Metode Penelitian (Pendekatan Kuantitatif, Kualitatif, dan R\&D). Bandung: Alfabeta.

. 2011. Metode Penelitian (Pendekatan Kuantitatif, Kualitatif, dan R\&D). Bandung: Alfabeta.

World Health Organization, 2010. The Sexsual and reproductive health of younger adolescents. 